\title{
Educational Quality Development for The Achievement to "Digital Island"
}

\author{
Journal of Communication and Public Relations \\ Vol. 1, No. 1, December 2021, 1-4 \\ P-ISSN: XXXX-XXXX \\ E-ISSN: XXXX-XXXX \\ DOI: https://doi.org/10.37535/105001120211
}

\author{
Setia Tika1, Puspitasari Puspitasari ${ }^{2}$ \\ 1,2 Institut Komunikasi dan Bisnis LSPR, Jakarta, Indonesia
}

\begin{abstract}
This paper aims to understand the Educational Quality Development for the achievement of "Digital Island" a corporate social responsibility (CSR) implementation in Harapan Island, Indonesia. To build a digital Island need quality human resources, technology, expert english language, good infrastructure, good cooperation with the factory ,some foreign industry and good social culture. This study explains why must choose youths Harapan Island because in this island regularly every year held CSR from China National Offshore Oil Corporation (CNOOC SES Ltd). Based on the findings of the research, the following conclusions were made. In general, students of MAN 1 Harapan Island,Thousand Island are quite enthusiastic in participating in Future Orientation training activities. The implementation of tutoring takes place conducively. The results of the diagram percentage of the achievement of the competency of the try out results are 2 students with the highest score $=87$ out of a total of 2 students who achieved a very good value range. Furthermore, $9 \%$ obtained a good range of values, $53 \%$ gained enough ranges, while the remaining $34 \%$ obtained a range of less values. With such results, all students are expected to be able to improve their motivation and learning efficiently and optimally referring to the results of a try out that is not satisfactory, the students must work harder in motivating themselves and further improve their fighting power and learning spirit.
\end{abstract}

Keywords: youth; welfare; soft skill; CSR

\section{Introduction}

Considering that the last two years from 2016 to 2018 the socio-economic conditions on Harapan Island were not good because it was caused by several factors, namely low education level and it was supported by data Number of Population Based on the level of formal education majority of the youth in Harapan Island are graduated in Senior High School totally 883 peoples about $40 \%$ from all of data number of population based on the level of formal education, high unemployment rate, poor infrastructure, poor quality of the population supported by data number of population based on level formal education about $40 \%$ and based on population of category of fisherman about 303 person, including signals even though the potential could one of them is tourism, but tourism is still hampered by the still minus human resources and infrastructures that are still minus, to overcome these problems, a program is needed to improve the quality of human resources and the quality of infrastructure and this is seen by CNOOC and CNOOC move and choose to implement CSR there through

Corresponding author:

Setia Tika, Postgraduate Programme, Institut Komunikasi dan Bisnis LSPR, JI K.H Mas Mansyur, Kav 35, Jakarta 10220

Email: setiatika90@gmail.com

Submitted: November, 2021; Reviewed: November, 2021; Published: December, 2021 
several programs such as education sector, health sector, economic sector, environtment sector, public facilities sector, and public relations activities sector. This research mostly talk about the quality of the youth in Harapan Island and one of the way to increase the quality of the youth need many cooperation from Local goverment in Harapan Island, oil company that held CSR, society in Harapan Island, PT Fun Entertainment and the youths in MAN 1 Jakarta in Harapan Island.

\section{Literature Review}

Reviewed from according to Buzan (2000), Mind mapping is an application that gives us the meaningful information to understand in a simple way. Mind Mapping Technique prepares the mind in a way that information can be used in logical and imaginary way to make an image in the brain. In Mind Mapping Technique first main idea is specified and then the linear view is explained. It is also useful for self and group in which it can have more effect than written review. This method is suitable for teachers and students for the recurrence and easy to understand hard topics. In addition, it also promotes student knowledge. This technique increases the creative power in new concepts and help to increase your motivation to study the students. Does the implementation of the technique presented by Buzan (2000) implemented in the social science subject of Primary and secondary class by using mind map method can bring changes to the education working system or not. And this study has been practiced by aiming to achieve the effectiveness. Mind mapping can be used for introducing the students with the principles and experiments of mind mapping,addition teacher teaching and making study more simple and joyful. To prepare notes, annual plan, session plan, daily plan, text and presentation, exams and for special education programs it is being used and seen as a best method in the world (Parikh, 2016).

Next literature review is describe about youth is best understood as a period of transition from the dependence of childhood to adulthood's independence. Adolescence is an important developmental stage when multiple systems are involved in a complex process that influences adolescent's thinking and planning about adulthood and future expectations. Thinking about the future and constructing perceptions of oneself in the future might have a bigger role during adolescence than during other developmental stages of life (Trempala \& Malmberg, 2002). However, according to some popular stereotypes, 'adolescence' is also a period when youth are notoriously short-sighted, oriented to the immediate rather than the future, unwilling or unable to plan ahead, and less capable than adults at envisioning the longer term consequences of their decisions and behaviours (Lovu,Haragus, and Roth, 2018).

\section{Methods}

This study was conducted in MAN 1 Harapan Island. In total 2 classes consist of grade XII science major and social major schools were selected to participate in the intervention study and totaly the students were given questionare about 53 students. Per province, classes were randomly assigned to the intervention or control group. Three classes ( $T 1 n=75 ; T 2 n=80$ ) were assigned to the control condition and did not receive the intervention, 6 classes (T1 $n$ $=75 ; \mathrm{T} 2 \mathrm{n}=80$ ) did receive the intervention. The same classes participated at both measurements Time 1 and Time 2. 


\section{Result and Discussion}

The results of the diagram percentage of the achievement of the competency of the try out results are 2 students with the highest score $=87$ out of a total of 2 students who achieved a very good value range. Furthermore, $9 \%$ obtained a good range of values, $53 \%$ gained enough ranges, while the remaining $34 \%$ obtained a range of less values. With such results, all students are expected to be able to improve their motivation and learning efficiently and optimally referring to the results of a try out that is not satisfactory, the students must work harder in motivating themselves and further improve their fighting power and learning spirit.

\section{Conclusion}

Based on the findings of the research, the following conclusions were made. In general, students of MAN 1 Pulau Harapan, Kepulauan Seribu are quite enthusiastic in participating in Future Orientation training activities. They show changes in mindset and courage towards future orientation. This is indicated by the more specific ideals they want to achieve, knowing the steps they must do, and knowing the solutions they can do when there are obstacles or concerns they feel. This shows that they have the desire to move forward and learn, innovate, and the courage to share stories and information.

\section{References}

Cresswell, John W. 2010.Research Design: Qualitative, Quantitative and Mixed Methods Approaches (3nd ed). Thousand Oaks California 91320. 2009 : Sage Publications

Daymond, C.,\& Holloway, I. (2002). Qualitative research methods in public relations \& Marketing communications. Yogyakarta : Bentang Pustaka.

Griffin, Em. 2006.A First Look At Communication Theory (5th ed).Boston: Mc-Graw-Hill

Lee, N., \& Kottler, P. (2005). Corporate social responsibility : doing the most good for your company and your cause.New Jersey : John Wiley and Sons, Inc.

Lincoln, Yvonna S and Egon G. Guba. 2009. Paradigmatic Controversies, Contradictions and Emerging Confluences.In Norman K.Denzin and Yvonna S.Lincoln (eds), Handbook of Qualitatives Research (3nd ed).Thosand Oaks :Sage Publications Inc :

Littlejohn, Stephen W.and Karen A.Foss.2008, Theories of Human Communication (9th ed).

Lovu, Bogdan-Mihai, Haragus, Teodor Paul, and Roth, Maria. 2018. Constructing future expectations in adolescence : relation to individual characteristics and ecological assets in family and friends.

Miller Katherine. 2005, Communication Theories, Perspectives, Processes, and Cotexts, Second Edition, P.29.

Pacanowsky, M.E.,\& Trujillo, O. (1982). Communication and Organizational culture. Western.

Parikh, Nikhilkumar D.2016. Effectiveness of Teaching of Teaching through Mind Mapping Technique.

Prado, Mafud, Merlo \& Neves. (2015). Corporate Social Responsibility : retail actions in Brazilian market.

Slavin, R.E. 1994. Educational Psychology: Theory and Practice (4th Edition). Boston : Allyn and Bacon. 
Smith,Ronald D.2013. Strategic Planning for Public Relations (4th Edition ).First Published by Routledge 711 Third Avenue, New York, NY 10017

Wibisono. ( 2007). Membedah konsep dan aplikasi corporate social responsibility. Surabaya : Media Grapka

World Business Council for Sustainable Development (WBCSD). (2002). Corporate Social Responsibility -The WBCSD's Journal.Geneva 